\title{
Supervisi Akademik Kepala Sekolah Taman Kanak-kanak Dimasa Pandemi Covid 19
}

\author{
Jhoni Warmansyah \\ Institut Agama Islam Negeri (IAIN) Batusangkar \\ jhoniwarmansyah@iainbatusangkar.ac.id
}

\begin{abstract}
The Covid 19 pandemic has an impact on the difficulty of school principals in carrying out academic supervision in their institutions in order to ensure the continuity of the quality of education in Kindergarten institutions. The purpose of this study is to determine the implementation of academic supervision of kindergarten school principals in the midst of the Covid 19 pandemic. This study used a qualitative method with explorative case studies. The study was conducted at the Samba Taruma Kindergarten in Bekasi Regency in 2019/2020. Sampling uses purposive sampling. Respondents used as research samples are the principal and 3 teachers. Data collection uses semi-structured interviews by making a list of questions. Data analysis uses thematic data analysis. The results showed the implementation of academic supervision amid the Covid 19 pandemic by the Head of the Samba Taruma Kindergarten was going well. This can be seen from the supervision process in the form of online daily discussions, assisting teachers to overcome problems, inventory the basic competency achievements, and provide feedback on evaluating the successful learning process.
\end{abstract}

Keywords: Academic supervision, principal of kindergarten, covid 19

\begin{abstract}
Abstrak: Pandemi Covid 19 membawa dampak terhadap sulitnya kepala sekolah melakukan supervisi akademik dilembaganya agar tetap menjamin berlangsungnya mutu pendidikan dilembaga Taman Kanak-Kanak. Tujuan penelitian ini yaitu untuk mengetahui pelaksanaan supervisi akademik kepala sekolah taman kanak-kanak ditengah pandemi Covid 19. Penelitian ini menggunakan pendekatan kualitatif dengan metode studi kasus eksploratif. Penelitian dilakukan di Taman Kanak-Kanak Samba Taruma Kabupaten Bekasi tahun 2019/2020. Pengambilan sampel menggunaakan purposive sampling. Responden yang dijadikan sampel penelitian yaitu kepala sekolah dan 3 orang guru. Pengumpulan data mengunakan wawancara semi-terstruktur dengan membuat list daftar pertanyaan. Analisis data menggunakan analisis data tematik. Hasil penelitian menunjukkan pelaksanaan supervisi akademik ditengah pandemi Covid 19 oleh Kepala Taman Kanak-Kanak Samba Taruma tetap berlangsung dengan baik. Hal ini tersebut terlihat dari proses supervisi secara daring berupa diskusi harian secara online, memberikan bantuan kepada guru pemecahan masalah, menginventarisir capaian kompetensi dasar (KD), dan melakukan umpan balik terhadap evaluasi proses pembelajaran yang telah berlangsung.
\end{abstract}

Kata Kunci: Supervisi Akademik, Kepala sekolah TK, Covid 19 


\section{PENDAHULUAN}

Kepala sekolah memiliki peran sentral dalam menentukan kemajuan lembaga pendidikan yang dipimpinnya untuk menjadi lembaga yang bermutu tinggi adalah sangat penting. Untuk dapat menjalankan posisi tersebut dibutuhkan kepala sekolah yang berkompeten dibidangnya, profesional dalam tugasnya, dan berkarakter baik seperti dalam amanat Menteri Pendidikan Nasional Nomor 13 tahun 2007 tentang standar kepala sekolah dan madrasah (PermendiknasRI, 2007). Sebagaimana dinyatakan dalam Permendikbud No 137/2014 yaitu standar PAUD, kepala sekolah TK/RA memiliki tanggungjawab/tugas untuk merencanakan program pengawasan akademik dalam rangka profesionalisme guru, melakukan supervisi akademik pada guru dengan menerapkan pendekatan dan teknik supervisi yang tepat, dan menindaklanjuti hasil supervisi akademik dalam rangka meningkatkan profesionalisme guru (Ministry of Education and Culture of Republic Indonesia, 2014).

Latiana et.al (2017), menyebutkan bahwa kepemimpinan kepala sekolah dilembaganya adalah sebagai fungsi administratif yang yang memiliki kemampuan dalam menetapkan standar untuk pemrograman pendidikan, termasuk kurikulum, penilaian, dan praktik pengajaran disekolah untuk memenuhi kebutuhan anak-anak. Salah satu fungsi supervisor yang dilakukan kepala sekolah adalah supervisi akademik. Pelaksanaan kegiatan supervisi akademik tersebut merupakan suatu pendekatan yang paling tepat sebagai suatu upaya pembinaan guru PAUD dalam menjalankan serta mengembangkan kompetensi profesional yang dimiliki serta sebagai instrumen dalam pengelolaan pembelajaran di Taman Kanak-Kanak secara efektif. Peran kepala sekolah sebagai supervisor disatuan pendidikan yang dipimpinnya yaitu memberikan pembinaan berupa bantuan, bimbingan, penilaian, pengamatan, dan arahan kepada guru taman kanak-kanak (Harimurti, 2019).

Kepala Taman Kanak-Kanak sebagai leader/pemimpin lembaga pendidikannya harus dapat mengontrol dan memastikan bahwa seluruh guru memperoleh pelayanan supervisi akademik yang baik. Setiap guru juga harus memperoleh layanan yang setara tanpa membeda-bedakan status sosial ekonomi agama, jenis kelamin, golongan, ras dan suku. Begitu juga dengan layanan kepada setiap anak harus sama dan tidak diskriminasi dalam proses pembelajaran dengan mengacu pada undang-undang perlindungan anak (Ittihad, 2019).

Supervisi akademik merupakan tugas pokok kepala sekolah di masingmasing unit yang dipimpinnya untuk dapat meningkatkan mutu dan kualitas satuan pendidikan yang berkelanjutan (Kurniawan et al., 2018). Dengan pelaksanaan layanan supervisi akademik yang terprogram dan 
berkesinambungan, maka akan memberikan dampak positif terhadap capaian layanan berupa proses pembelajaran yang bermutu yang diberikan guru kepada peserta didik (Leniwati \& Arafat, 2017). Sebagaimana penelitian yang dilakukan oleh (Gay, 2016), bahwa menunjukkan bahwa proses pembelajaran yang dibimmbing melalui seorang guru yang memiliki kualitas unggul akan meningkatkan prestasi anak.

Supervisi merupakan aktivitas pembinaan yang dilakukan oleh pimpinan sekolah yang terencana untuk dapat membantu para guru dan pegawai sekolah menjalankan tugas dan tanggung jawab dalam kerja secara efektif. Bantuan yang diberikan dalam pengembangan sumber daya guru dapat berupa bimbingan, dorongan, dan kesempatan untuk menumbuhkan kecakapan dan keahlian para guru. Pemberian layanan dan bantuan dalam meningkatkan kualitas guru berimplikasi terhadap meningkatnya kualitas belajar siswa mulai dari perencanaan pembelajaran sampai melakukan refleksi (Purwanto, 2014).

Supervisi akademik yang telah dilakukan kepala sekolah terhadap para gurunya akan membawa keuntungan dan pengaruh positif yaitu dapat meningkatkan meningkatkan kompetensi, memperbaiki metode pengajaran dapat sehingga dapat dikategorikan sebagai guru yang ideal di sekolah (Kusumawati, 2016). Hasil penelitian lain yang dilakukan oleh Hasanah dan Kristiawan (2019), menemukan bahwa terdapat relasi yang kuat dan signifikan antara pelaksanaan supervisi akademik yang dilakukan oleh kepala sekolah terhadap kinerja para guru disatuan pendidikannya. apabila pelaksanaan supervisi akademik yang dilakukan oleh kepala sekolah naik/meningkat maka berdampak kepada peningkatan terhadap kinerja para guru disatuan pendidikannya.

Hasil penelitian lain yang dilakukan oleh Hartono (2019), menyebutkan bahwa supervisi berkala yang dilakukan oleh pimpinan suatu lembaga pendidikan merupakan suatu upaya dalam mengembangakan dan meningkatkan pengelolaan di lembaga pendidikan anak usia dini (PAUD). Sejalan dengan penelitian tersebut, hasil penelitian yang dilakukan oleh Modjo (2018), menemukan bahwa karakteristik dari subjek belajar perlu dipertimbangkan dalam memilih ketepatan model supervisi pembelajaran yang akan digunakan, hal ini karena rentang usia anak masih dalam tahap pra-operasional. Model supervisi pembelajaran yang dapat digunakan guru untuk menumbuhkan imajinasi di dalam diri anak salah satunya supervisi pembelajaran Moliti'O.

Dampak pandemi Covid-19 sangat meluas hampir di seluruh negara didunia, menyasar kepada sektor-sektor penting dalam suatu negara, salah satu sektor yang paling terkena dampak di Indonesia adalah sektor pendidikan (Syah, 2020). Data terakhir sudah berada pada angka 7,2 juta orang yang positif terkena 
virus tersebut dan di Indonesia sendiri (4/6) sudah pada angka 40 ribu lebih penduduk terinveksi, mulai dari usia lanjut sampai balita menjadi korban karena efek mematikan dari virus ini (Gugus Tugas Nasional, 2020). Pemerintah melalui kementerian pendidikan dan kebudayaan Republik Indonesia (Kemendikbud RI) mengambil keputusan untuk menuntup sekolah sementara dan mengalihkan proses pembelajaran jarak jauh secara daring mulai dari pendidikan paling dasar (PAUD) sampai pendidikan tinggi. Hal tersebut ditujukan agar memutus mata rantai penyebaran virus yang masif karena sekolah merupakan salah satu kawasan yang sangat rentan penyebarannya (Kemendikbud, 2020).

Dampak penutupan sekolah di satuan pendidikan anak usia dini (PAUD) yaitu terjadi perubahan pengalihan proses belajar dari sekolah ke rumah, sehingga sekarang seluruh kegiatan manusia menjadi serba online termasuk kegiatan pembelajaran disekolah, dimana pusat kegiatan berasal dari rumah masing-masing. Semua kegiatan publik beralih secara keseluruhan tersentralisasi dari rumah. Realitas yang terjadi tersebut merupakan hal yang pertama dan baru dalam dunia pendidikan secara global utamanya dalam dunia pendidikan anak usia dini (PAUD) (Muhdi \& Nurkolis, 2021). Tatanan kehidupan baru (new normal), mengharuskan semua pihak baik orangtua, guru maupun peserta didik harus siap beralih menggunakan pendekatan belajar yang jauh berbeda dari biasanya yaitu pemanfaatan media teknologi informasi dan media elektronik guna menunjang keberhasilan proses pengajaran dengan sistem yang baru. (Haerudin et al., 2020).

Di Taman Kanak-Kanak Samba Taruma Kabupaten Bekasi, sistem pembelajaran jarak jauh dilakukan dengan menggunakan berbagai cara seperti dengan memanfaatkan Whatsapp grup (WAG), google classroom, acara televisi, platform belajar online yang di fasilitasi oleh kemendikbud, atau pemberian panduan bermain/tugas proyek bersama orangtua. Keseluruhan model dan startegi pembelajaran jarak jauh tersebut disesuaikan dengan arahan Dinas Pendidikan dan Bupati yaitu agar tidak memberatkan peserta didik saat belajar dirumah dengan tetap mengacu pada capaian minimal kompetensi dasar (KD) yang harus dipenuhi saat belajar secara daring dimasa pandemi Covid-19. Selain hal tersebut yang perlu dipertimbangkan adalah keikutsertaan orangtua dan lingkungan tempat tinggal peserta didik, agar pembelajaran daring dapat tetap berjalan dengan baik di rumah (wawancara kepala sekolah).

Berdasarkan informasi terkini, sejak diberlakukannya proses pengalihan pembelajaran dari sekolah kerumah yang dikenal dengan istilah sistem belajar dalam jaringan/daring, masa tanggap darurat pandemi Covid-19 untuk pembukaan sekolah di era new normal hanya berlaku pada sekolah di zona hijau. Oleh karena itu sebagian sekolah masih menggunakan sistem daring dalam proses pembelajaran anak. Hampir empat bulan berjalan proses tersebut, yang 
mengharuskan kepala sekolah untuk merubah cara atau strategi supervisi yang diberikan kepada gurunya, khususnya yang sangat terkait dengan pelaksanaan supervisi akademik.

Dengan perubahan sistem dan cara belajar, maka model supervisi yang semula masuk kelas dalam pengawasannya, saat ini supervisi dilakukan dengan sistem daring/jarak jauh. Hal tersebut sejalan dengan hasil penelitian yang dilakukan oleh Kasmawati (2020), menyebutkan bahwa supervisi merupakan upaya pembimbingan dan perbaikan dalam membantu guru dalam mengelola proses pembelajaran. Keterbatasan dalam melakukan supervisi akademik ditengah kondisi pandemi Covid-19 dapat memanfaatkan IT dengan google form, agar pelaksanan supervisi dapat terlaksana secara efektif dan efisien. Hasil penelitian senada juga yang dilakukan oleh Elfidawati (2020) menemukan bahwa dalam peningkatan kedisiplinan guru, supervisi dapat dilakukan dengan form aktivitas mingguan dengan pengecekan observasi, diskusi dan pengecekan secara berkala merupakan alternatif pemecahan masalah dalam pelaksanakan supervisi di tengah kondisi pandemi Covid-19.

Walaupun banyak penelitian sebelumnya bahwa pelayanan supervisi akademik merupakan tugas seorang kepala sekolah sebagai fungsi manajerial yang memberikan dampak positif terhadap peningkatan kinerja guru guru dalam proses pembelajsaran, namun bagaimana proses perubahan supervisi akademik yang terjadi dilapangan belum ada yang mengkaji secara jelas. Untuk itu penelitian ini berupaya mengkaji tentang bagaimana pelaksanaan supervisi yang dilakukan kepala sekolah Taman Kanak-Kanak Samba Taruma dimasa pandemi Covid-19?

\section{METODE PENELITIAN}

Penelitian ini menggunakan pendekatan kualitatif dengan metode studi kasus eksploratif. Penelitian ini dilakukan Taman Kanak-Kanak Samba Taruma di Kabupaten Bekasi pada tahun akademi 2019/2020. Pengambilan sampel dalam penelitian menggunaakan teknik purposive sampling, yaitu pengambilan sampel non random yang didasarkan pada pertimbangan tertentu (Sugiyono, 2017). Dalam penelitian ini untuk menentukan ukuran sampel maka dilihat dari kekayaan dan kedalaman deskripsi. Menurut Guetterman (2018), yang dijadikan patokan dan pegangan dalam ukuran sampel adalah kekayaan informasi uang diperoleh bukan pada opini representatif dan pandangan. Responden yang dijadikan sampel dalam penelitian ini merupakan kepala sekolah 3 orang guru. Untuk kerahasiaan penelitian ini, maka responden diberi inisial K, G1, G2, dan G3. Wawancara semi-terstruktur dilakukan terhadap responden dengan membuat list daftar pertanyaan yang telah disusun dan dikembangkan sendiri oleh peneliti berdasarkan kajian literatur yang ada. Untuk teknik wawancara 
dilakukan dengan via telepon selular guna mengikuti protokol kesehatan yang aman ditengah masa pandemi Covid-19 bagi para responden. Semua proses wawancara, dilakukan dengan memperoleh persetujuan dan izin yang ditandatangani, direkam secara audio dan kemudian ditranskrip secara verbal.

Tabel 1. Data Responsen Yang Menjadi Sampel

\begin{tabular}{clccc}
\hline Initial & Jenis Kelamin & Usia & Status & Pendidikan \\
\hline K1 & Perempuan & 45 & Menikah & S2 \\
\hline G1 & Perempuan & 23 & Belum Menikah & S1 (Proses) \\
\hline G2 & Perempuan & 23 & Menikah & S1 (Proses) \\
\hline G3 & Perempuan & 22 & Belum Menikah & S1 (Proses) \\
\hline
\end{tabular}

Analisis dan interpretasi data merupakan bagian yang paling krusial dalam penelitian kualitatif. Analisis data menggunakan analisis data tematik, hal tersebut dianggap yang paling sesuai pada penelitian yang berupaya untuk mengeksplorasi dari interpretasi yang digali dalam proses penelitian (Braun et al., 2019). Analisis tematik digunakan untuk menganalisis klasifikasi dan menyajikan tema atau pola yang memiliki keterkaitan dengan data. Analisis ini adalah yang paling cocok untuk penelitian yang menemukan untuk menggali menggunakan interpretasi. Analisis ini menawarkan komponen sistematis untuk analisis data karena memungkinkan peneliti untuk mengaitkan analisis frekuensi tema dengan salah satu dari seluruh konten (Alhojailan, 2012). Oleh karena itu, peneliti harus memahami data dengan menemukan dan menafsirkannya

\section{HASIL DAN PEMBAHASAN}

Berdasarkan hasil temuan penelitian ditemukan bahwa fungsi manajerial kepala sekolah di Taman Kanak-Kanak Samba Taruma dalam melakukan kontrol terhadap mutu pendidikan melalui supervisi akademi guna menjamin tetap berjalannya dan terkontrol mutu pembelajaran selama pandemi Covid 19 yang mengharuskan proses pembelajaran harus dialihkan dari rumah. Hasil wawancara dengan Kepala TK Samba Taruma Kabupaten Bekasi, cara yang dilakukan dalam melakukan supervisi akademik di lembanganya ditengah pandemi Covid-19 yaitu adalah

Pertama, diskusi harian secara online. Pelaksanaan diskusi harian dengan majelis guru dilakukan setiap pagi secara online sebelum guru berinteraksi dan berkomunikasi melalui orangtua anak memberikan pembelajaran secara daring kepada anak dan melakukan pembelajaran dengan anak. Kepala sekolah memastikan tugas-tugas harian untuk menstimulasi perkembangan anak mempunyai panduan yang jelas untuk orangtua sebagai bantuan pelaksana tugas guru dirumah dimasa pandemi Covid-19, agar dapat 
dilaksanakan anak dengan tetap menerapkan strategi belajar anak usia dini yaitu dengan cara bermain yang menyenangkan dan bermakna. Kepala sekolah membaca skenario tugas yang telah dirancang guru dan memberikan masukan terhadap lembar kerja anak (LKA) yang telah dibuat guru agar tidak terlalu berat dan sulit bagi orangtua karena beban kerja lain yang masih banyak dihadapi orangtua. Pemanfaatan Whatsapp Grup untuk diskusi dalam memecahkan masalah-masalah yang ditemukan saat suasana pembelajaran jarak jauh seperti sekarang ini merupakan alternatif utama yang paling efektif untuk digunakan oleh pihak sekolah.

Hal tersebut juga diperkuat dengan wawancara yang dilakukan terhadap ketiga guru kelas yang menyatakan bahwa kepala sekolah selalu mengecek panduan skenario pembelajaran termasuk LKA yang akan diberikan kepada orangtua agar sesuai dengan perkembangan anak dan tidak menyulitkan orangtua melalukan dirumah bersama anak, selain itu kepala sekolah selalu berdiskusi secara online melalui Whatsapp Grup (WAG), untuk mengecek kehadiran dan berkomunikasi secara intensif baik secara telepon langsung, WAG, maupun Video Call untuk memastikan kehadiran absensi, kondisi pendampingan orangtua oleh guru, keadaan dan kesehatan para murid dan guru ditengah pandemi Covid-19.

Pelaksanaan supervisi akademik yang dilakukan kepala sekolah memiliki tujuan untuk peningkatan kualitas proses pembelajaran yang diberikan oleh guru kepada peserta didik yaitu dapat dilakukan melalui pemberian masukan/saran, pembimbingan, dan pengembangan kemampuan guru sehingga dapat memiliki pengaruh positif berupa peningkatan kompetensi guru yang dimiliki guru (Sarifudin, 2019). Hal ini sesuai dengan penelitian yang dilakukan oleh Haryono (2017), terdapat pengaruh kepemimpinan kepala sekolah dan supervisi akademik terhadap motivasi kerja dan kinerja guru.

Kedua, kepala sekolah memberikan bantuan kepada guru (Problem Solving). Kepala sekolah memberikan bantuan terkait pertanyaanpertanyaan (keluhan) dan masukan saran dari orang tua terkait pengiriman tugas rutin guru melalui rancangan program mingguan (RPPM) sekali seminggu yang diberikan kepada anak melalui orangtua untuk dapat dilaksanakan setiap hari dirumah. Kepala sekolah memastikan lembar kerja anak (LKA) yang diberikan melalui grup kelas wali murid mendapatkan panduan dan pendampingan yang baik dan jelas dalam pembelajaran secara daring tersebut. Kepala sekolah juga melakukan kontrol untuk memastikan pengiriman dan pelaporan hasil karya anak setiap minggu dengan membaca serta melihat dokumentasi kegiatan/hasil karya yang dikirimkan orangtua dan diproses penilaiannya oleh guru kelas masing-masing. Bila terdapat kesulitan kepala sekolah membantu dan mendampingi proses penilaian tersebut. 
Pemberian bantuan dari kepala sekolah kepada para guru, dari ketiga guru menyatakan penyataan yang sama yaitu kepala sekolah sangat membantu mengatasi masalah terkait dengan keluhan-keluhan orangtua dalam membelajarkan anak dirumah yang dipusingkan dengan bertambahnya beban kerja dan aktivitas orangtua. Kepala sekolah memberikan pemahaman terkait dengan pemberian panduan tugas bermain sambil belajar bersama orangtua merupakan wadah/sarana untuk dapat menstimulasi 6 aspek perkembangan anak. Selain itu kepala sekolah juga meminta forward Whatsapp Grup (WAG) orangtua berupa laporan pemberian tugas mingguan sesuai RPPM dan feedback laporan perkembangan siswa yang diberikan oleh orangtua kepada guru kelas berupa foto dan video kegiatan anak dirumah sebagai bukti proses pembelajaran tetap berlangsung meskipun dengan sistem pembelajaran jarak jauh.

Melalui pelaksanaan supervisi akademik kepala sekolah dapat/mampu menampung setiap persoalan masalah yang ditemui/dihadapi oleh para guru dalam proses pengajaran untuk dapat menemukan strategi dari pemecahan masalah yang ada. sebagaimana penelitian yang dilakukan oleh Suwartini (2017), menunjukkan bahwa pelaksanaan supervisi akademik kepala sekolah dan tingginya profesionalisme yang dimiliki guru dalam mengajar berdampak positif terhadap peningkatan mutu pendidikan dilembaga yang dipimpinnya.

Sejalan dengan hasil penelitian tersebut Saiful Bahri (2014), menyebutkan supervisi akademik adalah suatu wujud nyata dalam mendorong para guru untuk meningkatkan/mengembangkan kemampuan yang dimilikinya dalam mencapai tujuan pembelajaran. Oleh sebab itu, dasar dari pelaksanaan supervisi akademik bukan menilai unjuk kerja guru dalam pengelolaan proses pembelajaran di sekolah, melainkan peningkatan profesionalisme. Kompetensi yang memadai yang dimiliki oleh guru berdampak pada professional guru dalam bekerja.

Ketiga, kepala sekolah menginventarisir capaian kompetensi dasar (KD). Setiap capaian kompetensi dasar yang telah dicapai maupun yang belum dibuatkan dalam bentuk sebuah portofolio online yang dapat dimasukkan kedalam google drive. Cara yang dilakukan guru yaitu dengan menginventarisasi hasil-hasil karya anak dengan membuatkan folder kumpulan hasil-hasil karya anak setiap minggu per/anak untuk memudahkan guru memberikan penilaian proses perkembangan anak di akhir semester. Inventaris ini menjadi sangat penting untuk capaian target kompetensi dasar (KD) yang telah dan belum terpenuhi. Kepala sekolah melalui whatsapp grup atau aplikasi zoom berdiskusi tentang bagaimana cara memberikan penilaian proses perkembangan anak melalui laporan perkembangan yang disampaikan oleh orangtua sebagai bantuan pelaksana tugas harian sekolah dirumah. 
Hasil wawancara dengan ketiga guru kelas disimpulkan bahwa kepala sekolah meminta para guru kelas untuk melakukan penilaian perkembangan anak yang tidak dapat dilakukan secara langsung melainkan dengan laporan foto/video kegiatan anak bersama orangtua dirumah. Setiap kompetensi dasar (KD) yang belum tercapai dengan maksimal diminta untuk mengkomunikasikan kepada orangtua dirumah agar tetap dapat berkembang dengan baik.

Kegiatan supervisi akademik disekolah dapat memberikan dampak baik/positif terhadap peningkatan guru dalam kemampuan menyusun administrasi penilaian. Selaku supervisor pendidikan peningkatan kemampuan guru dapat dilakukan dengan pengarahan dan bimbingan dari kepala sekolah. Pelaksanaan supervisi akademik yang intensif dan berkelanjutan, akan berdampak terhadap peningkatan kinerja guru yang sejalan dengan lebih berkualitasnya proses pengajaran dikelas dan menjadikan output sekolah juga makin berkualitas (Astuti, 2017).

Terakhir, Kepala sekolah melakukan umpan balik. Kepala sekolah memberikan masukan, penguatan dan umpan balik terhadap evaluasi pembelajaran yang telah berlangsung melalui whatsapp grup walimurid terhadap proses pembelajaran secara daring yang telah terlaksana selama satu semester genap T.A 2019/2020. Secara umum respon dari wali murid beragam dengan pelasanaan pembelajaran daring tersebut. Selanjutnya kepala sekolah selalu berdiskusi secara intensif dengan majelis guru baik bertemu luring disekolah dengan memenuhi protokol kesehatan maupun lewat whatsapp grup guru dan room melakukan rapat evaluasi menyeluruh terkait kendala dan tantangan yang dihadapai dan ditemukan saat pelaksanaan pembelajaran secara daring oleh orangtua, untuk persiapan tahun ajaran baru yang berkemungkinan sama pelaksanaannya karena wabah Covid 19 belum menunjukkan akan berakhir dalam waktu dekat. Supervisi akademik tetap harus dilaksanakan sengan baik dengan strategi baru yang disesuaikan kondisi dan situasi sekolah masingmasing.

Kinerja guru tergambar dari penilaian kinerja yang diukur dari seberapa besar kontribusi individu guru dalam sebuah institusi yang dilaksanakan pada organisasi. Supervisi akademik adalah cara penilaian terhadap kinerja guru dengan tahapan perencanaan siklus yang sistematis, melalui proses pemantauan yang cermat dan dengan cara yang hati-hati. Pelaksanaan supervisi akademik yang dijalankan oleh kepala sekolah akan menghasilkan umpan balik/feedback dalam pembenahan/perbaikan mutu dari kinerja para guru di sekolah (Khoeriyah, 2015). 


\section{KESIMPULAN}

Hasil penelitian ini memberikan suatu implikasi penting bahwa dimasa pandemi Covid-19 ini perlu tetap adanya pelaksanaan supervisi akademik oleh kepala sekolah sebagai penanggung jawab pelaksana proses pembelajaran yang berlangsung dilembaga pendidikan yang dipimpinnya. Pendampingan, pembimbingan, dan pengawasan yang dilakukan oleh kepala sekolah untuk memastikan jalannya proses pembelajaran dapat berjalan dengan baik merupakan fungsi supervisor kepala sekolah disatuan pendidikan yang dipimpinnya. Banyak beragam pelaksanaan supervisi akademik yang dapat dijadikan contoh dan acuan dalam pelaksanaan tatap muka namun tidak efektif dilakukan secara daring. Pelaksanaan supervisi akademik oleh kepala sekolah ditengah pandemi Covid-19 ini dapat dilakukan dengan diskusi harian secara online, memberikan bantuan kepada guru pemecahan masalah, menginventarisir capaian kompetensi dasar (KD), dan melakukan umpan balik terhadap evaluasi proses pembelajaran yang telah berlangsung. Untuk itu kepala sekolah perlu aktif melakukan supervisi akademik terhadap guru melalui pembinaan secara berkesinambungan.

\section{REFERENSI}

Alhojailan, M. I. (2012). (2012). Thematic Analysis: A critical review of its process and evaluation. In WEI International European Academic Conference, $8-21$.

Astuti, S. (2017). Supervisi Akademik Untuk Menigkatkan Kompetensi Guru Di SD Laboratorium UKSW. Scholaria: Jurnal Pendidikan Dan Kebudayaan, 7(1), 49. https://doi.org/10.24246/j.scholaria.2017.v7.i1.p49-59

Braun, V., Clarke, V., Hayfield, N., \& Terry, G. (2019). Thematic analysis. In Handbook of research methods in health social sciences (pp. 843-860.). http://fnm.tums.ac.ir/userfiles/iao/workshop/5-thematicanalysisslidesprof.braun.pdf

Elfidawati, E. (2020). Peningkatan Kedisiplinan Dan Kualitas Pembelajaran Guru Pada Masa Pandemi Covid-19 Melalui Supervisi Akademik Di Sd 009 Kuala Terusan Pangkalan Kerinci. Jurnal Kepemimpinan Dan Kepengurusan Sekolah, https://doi.org/http://dx.doi.org/10.34125/kp.v5i2.564

Gay, M. (2016). Tugas Dan Tantangan Guru: Membangun Kualitas Guru Menuju Pengembangan Pendidikan Bermutu. EDUKASI, 13(2), 260271. https://doi.org/10.33387/j.edu.v13i2.47

Guetterman, T. C. (2018). Descriptions of sampling practices within five 
approaches to qualitative research in education and the health sciences. Forum Qual Soc Res. 2015, 16(2), 25.

Gugus Tugas Nasional, T. (2020). Berita Terkini, Data Sebaran Global dan Indonesia Kasus COVID 19. Gugus Tugas Percepatan Penanganan COVID-19. https://covid19.go.id/

Haerudin, Cahyani, A., Sitihanifah, N., Setiani, R. N., Nurhayati, S., Oktaviana, V., \& Sitorus, Y. I. (2020). Peran Orangtua Dalam Membimbing Anak Selama Pembelajaran Di Rumah Sebagai Upaya Memutus Covid-19. Universitas Singaperbangsa Karawang, 3(1), 1-12.

Hardono, Haryono, A. Y. (2017). Kepemimpinan Kepala Sekolah , Supervisi Akademik, dan Motivasi Kerja dalam Meningkatkan Kinerja Guru. Jurnal Unnes, 6(1), 1-8.

Harimurti, E. R. (2019). Supervisi Akademik Dalam Upaya Pembinaan Kompetensi Profesional Guru Pendidikan Anak Usia Dini (PAUD). Buab Hati, 6(2), 78. https://buahhati.stkipgetsempena.ac.id/?journal=home\&page=article\& op= view\&path $\% 5 \mathrm{~B} \% 5 \mathrm{D}=87$

Hartono, H. (2019). Supervisi Berkala Dalam Upaya Meningkatkan Pengelolaan Lembaga Pendidikan Anak Usia Dini (PAUD) Se Kecamatan Driyorejo Tahun 2018. Didaktis: Jurnal Pendidikan Dan Ilmu Pengetahuan, 19(1). https://doi.org/10.30651/didaktis.v19i1.2553

Hasanah, M. L., \& Kristiawan, M. (2019). Supervisi Akademik dan Bagaimana Kinerja Guru. Tadbir: Jurnal Studi Manajemen Pendidikan, 3(2), 97. https://doi.org/10.29240/jsmp.v3i2.1159

Ittihad, I. (2019). Supervisi Akademik Kepala Sekolah terhadap Manajemen Pembelajaran PAUD. PALAPA, 7(1), 99-107. https://doi.org/10.36088/palapa.v7i1.186

Kasmawati, K. (2020). Pemanfaatan Aplikasi Google Form dalam Pelaksanaan Supervisi Akademik di Masa Pandemi Covid-19 pada Sekolah Binaan di Kabupaten TakalarJurnal Sipatokkong Bpsdm SulseL. Jurnal Sipatokkong Bpsdm SulseL, 1(2), 143-147. http://ojs.bpsdmsulsel.id/index.php/sipatokkong/article/view/28

Kemendikbud. (2020). Surat Edaran Mendikbud Nomor 3 Tabun 2020 tentang Pencegaban COVID-19 pada Satuan Pendidikan, dan Nomor 36962/MPK.A/HK/2020 tentang Pembelajaran secara Daring dan Bekerja dari Rumah. Biro Kerjasama Dan Hubungan Masyarakat Kementerian Pendidikan Dan Kebudayaan. https://www.kemdikbud.go.id 
186 | Tadbir : Jurnal Studi Manajemen Pendidikan, Vol. 4, No. 2, 2020

Khoeriyah, S. W. (2015). Pengaruh Supervisi Akademik Terhadap Kinerja Guru SMP IT Yaspida Sukabumi. Tadbir Muwabbid, 4(2), 86-91. https://doi.org/http://dx.doi.org/10.30997/jtm.v4i2.344

Kurniawan, D., Dwikurnaningsih, Y., \& Sulasmono, B. S. (2018). Evaluasi Program Supervisi Akademik di PAUD Swasta. Kelola: Jurnal Manajemen Pendidikan, 5(2), 107-123. https://doi.org/10.24246/j.jk.2018.v5.i2.p107-123

Kusumawati, D. (2016). Supervisi Akademik Kepala Sekolah Terhadap Manajemen Pembelajaran Paud. Satya Widya, 32(1), 41. https://doi.org/10.24246/j.sw.2016.v32.i1.p41-48

Latiana, L., Pranoto, S., \& Semarang, U. N. (2017). Academic Supervision Model for the Early Childhood Education in the Municipality of Semarang. The Journal of Educational Development, 5(3), 434-444. https://doi.org/10.15294/jed.v5i3.18132

Leniwati, L., \& Arafat, Y. (2017). Implementasi Supervisi Akademik Kepala Sekolah Untuk Meningkatkan Kinerja Guru. JMKSP Jurnal Manajemen Kepemimpinan Dan Supervisi Pendidikan), 2(1), 106-114. https://doi.org/http://dx.doi.org/10.33369/jmksp.v2i1.1158

Ministry of Education and Culture of Republic Indonesia. (2014). National Standard of Early Children Education. 1-15.

Modjo, U. (2018). Model Supervisi Pembelajaran Molit'o Paud. JIV, 13(1), 6166. https://doi.org/10.21009/JIV.1301.7

Muhdi, \& Nurkolis. (2021). Keefektivan Kebijakan E-Learning berbasis Sosial Media pada PAUD di Masa Pandemi Covid-19. Jurnal Obsesi: Jurnal Pendidikan Anak Usia Dini, 5(1), 212-228. https://doi.org/10.31004/obsesi.v5i1.535

PermendiknasRI. (2007). Peraturan Menteri Pendidikan Nasional Republik Indonesia Nomor 13 Tahun 2007 Tentang Standar Kepala Sekolah/Madrasah. 1(1), 1-17. https://bsnp-indonesia.org/id/wpcontent/uploads/tenaga/Permen_13_Th-2007.pdf

Purwanto, N. (2014). Administrasi dan supervisi pendidikan. Remaja Rosdakarya.

Saiful Bahri. (2014). Supervisi Akademik Dalam Peningkatan Profesionalisme Guru. Visipena Journal, 5(1), 100-112. https://doi.org/10.46244/visipena.v5i1.236

Sarifudin, A. (2019). Peningkatan Kinerja Guru Dalam Implementasi Penilaian Sistem Sks Melalui Supervisi Akademik Pengawas Sekolah. Edukasi 
Islami,

$$
8(2)
$$

417-434.

https://doi.org/http://dx.doi.org/10.30868/ei.v8i2.539

Sugiyono. (2017). Metode Penelitian Bisnis: Pendekatan Kuantitatif, Kualitatif, Kombinasi, dan R※D. CV. Alfabeta.

Suwartini, E. A. (2017). Supervisi Akademik Kepala Sekolah, Profesionalisme Guru Dan Mutu Pendidikan. Jurnal Administrasi Pendidikan, 4(2), 1-9. https://doi.org/https://doi.org/10.17509/jap.v24i2.8294

Syah, R. H. (2020). Dampak Covid-19 pada Pendidikan di Indonesia: Sekolah, Keterampilan, dan Proses Pembelajaran. SALAM: Jurnal Sosial Dan Budaya Syar-I, 7(5). https://doi.org/10.15408/sjsbs.v7i5.15314 
188 | Tadbir : Jurnal Studi Manajemen Pendidikan, Vol. 4, No. 2, 2020

This page belongs to the TADBIR : Jurnal Studi Manajemen Pendidikan

TADBIR : Jurnal Studi Manajemen Pendidikan vol. 4 , no. 2, November 2020

IAIN Curup - Bengkulu | p-ISSN 2580-3581; e-ISSN 2580-5037 